\title{
RECOVERY FROM STRUCTURAL CHANGES PRODUCED IN ADRENAL GLANDS OF THE RAT BY ADMINISTRATION OF CORTISONE*
}

\author{
BY
}

\author{
MARJORIE B. PATTERSON, $\uparrow$ HENRY S. SIEGEL, and R. H. FREYBERG \\ From the Hospital for Special Surgery, and the Department of Internal Medicine, Cornell University \\ Medical College, New York, and the Department of Pathology, Kings County Hospital, Brooklyn, N.Y.
}

(RECEIVED FOR PUBLICATION AUGUST 4, 1953)

In order to determine how cortisone might be used with the greatest practical value as a therapeutic agent for patients with a chronic illness such as rheumatoid arthritis, clinical studies were undertaken to observe the result of relatively small doses with definite anti-rheumatic effect given over a period of one year or more. As judged by clinical findings, some patients with rheumatoid arthritis tolerated well the prolonged use of cortisone, while others did not. Laboratory tests to determine the responsiveness of the human adrenal gland to stimulation by corticotropin, shortly after discontinuance of prolonged cortisone treatment, showed a satisfactory physiological response in the majority of the patients. In parallel with these observations, animal studies were conducted to determine whether daily injections of cortisone acetate for a period of time comparable to one year in man would produce irreversible structural changes in the rat adrenal gland.

\section{Method of Study}

Material.-Albino rats of the Sherman strain, 3 months old, were used. All animals were obtained from the dealer at the same time. The female rats weighed 190 to $240 \mathrm{~g}$., and the males 190 to $260 \mathrm{~g}$. All rats were housed under the same conditions and were given water and a complete Rockland stock diet ad libitum, with the exception that in one series food was restricted to provide undernourished control animals. The cortisone acetate used in these studies was the usual suspension $(25 \mathrm{mg}$. $/ \mathrm{ml}$.) injected intramuscularly into arthritic patients. The diluent employed for control was the vehicle used by the

* This work was supported (in part) by a grant in aid from the National Institutes of Health of the Public Health Service, and (in part) by the Fund for Research in Rheumatic Diseases, Hospital for Special Surgery.

† Eli Lilly Research Fellow in Rheumatic Diseases. manufacturer for suspending the cortisone acetate, a saline solution containing suspending agents and $1 \cdot 5$ per cent. benzyl alcohol.

Experimental Animals.-Intramuscular injections of cortisone acetate were given to 25 male and 25 female rats. On the first day they received $9 \mathrm{mg}$. cortisone acetate in $0.6 \mathrm{ml}$. of the suspending vehicle, and on each of the succeeding 10 days each rat received $3 \mathrm{mg}$. steroid in $0.2 \mathrm{ml}$. vehicle. The total amount of cortisone acetate given during this 11-day injection period was $39 \mathrm{mg}$. to each rat. The daily dose of $3 \mathrm{mg}$. was calculated to be ten times the equivalent of a human daily dose of $100 \mathrm{mg}$., based on comparative average body weights. Control animals were also injected for 11 days, subsequently referred to as "the injection period".

The cortisone-treated rats were divided into five groups of ten animals each, with five males and five females in each group. Each group was killed at different intervals after the last injection: $1,3 \cdot 5$, 7,14 , and 30 days.

Controls.-A group of 66 rats, 33 male and 33 female, used as controls, was divided into three series:

Series I, 4 males and 4 females, untreated, served as controls for growth and development over the 41-day period of observation (11 days of injection and 30 days of recovery).

Series II, 16 females and 16 males, were injected intramuscularly with the diluent only. These animals received $0.6 \mathrm{ml}$. diluent on the first day and $0.2 \mathrm{ml}$. daily on each of the succeeding 10 days. This series was divided into four equal groups, and one group was killed at each of four different periods after the last injection: $1,7,14$, and 30 days.

Series III, 13 males and 13 females were not 
injected and were fed a restricted diet so that the weight of each rat in this series was paired with that of a rat of the same sex in the cortisone-treated rats (Series IV). The animals in the three groups of this series were killed at 1,7 , and 30 days after the injection period.

Procedure.-All rats were weighed every second day. They were killed rapidly by the inhalation of coal gas for one minute. Autopsies were performed at once, and the adrenal glands were the first organs to be removed. After separation from the surrounding fat, the glands were weighed immediately on an analytical balance and fixed in 10-per cent. formalin. Histologic sections $15 \mu$ thick, were prepared from the mid-portion of the left adrenals according to the frozen section technique, and were stained with Sudan IV. The right adrenal glands were embedded in paraffin and sectioned serially, and representative samples were stained with haematoxylin and eosin.

The extent of structural changes in the adrenal glands was determined by weighing the glands and by study of the histologic alterations. The haematoxylin-eosin stain permitted comparisons to be made of the width of the cortex and the size and compactness of the cytoplasm of the cells in the fascicular and reticular zones. The Sudan IV stain indicated the amount of lipid present.

\section{Results}

Body Weight.-During the injection period all cortisone-treated rats showed a progressive decrease in body weight in direct proportion to the amount of cortisone injected (Fig. 1). $24 \mathrm{hrs}$ after the last injection the female rats had lost an average of $27 \mathrm{~g}$. (13 per cent. of the pre-injection weight), and the male rats had lost an average of $23 \mathrm{~g}$. (11 per cent. of the pre-injection weight). On the 7 th day of the recovery period the males had reached their preinjection weight and then equalled the weight of the

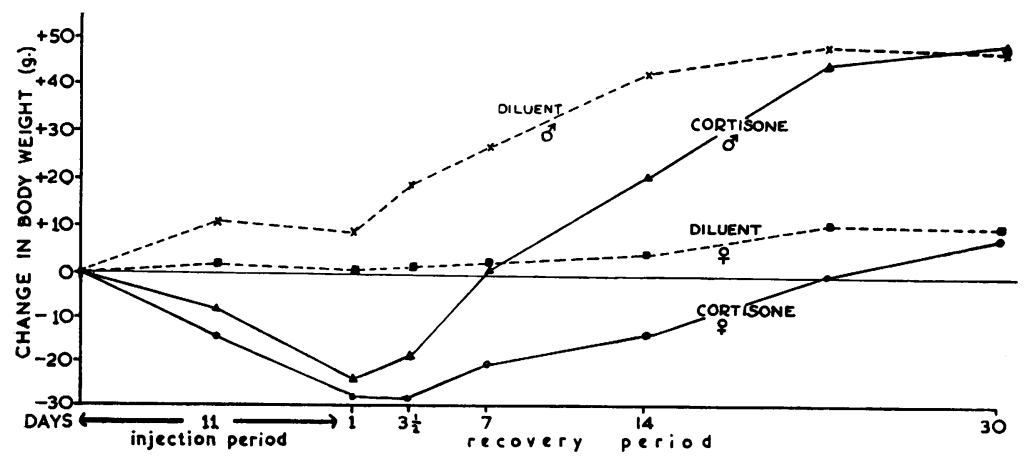

Fig. 1.-Average changes in body weight during cortisone injection and recovery period. diluent controls. The females recovered more $\stackrel{\overparen{D}}{\stackrel{D}{丂}}$ slowly; they reached their pre-injection weight on the 22nd day and equalled the weight of the diluent- $-\frac{0}{\infty}$ injected rats on the 30th post-treatment day. At all times the weights of the diluent-treated control ratso were less than those of the untreated controls.

Adrenal Weight.-At the end of the injection $\frac{\bar{\sigma}}{\bar{\omega}}$. period the average weight of both adrenal glands $\overrightarrow{\mathbb{D}}$ of the cortisone-treated female rats (Series IV, $\frac{\Omega}{\sim}$ Group 1) was $47 \mathrm{mg}$., which was distinctly less than क the average $(62 \mathrm{mg}$.) of the female inanition control $\overrightarrow{0}$ rats, and the average $(67 \mathrm{mg}$.) of the female diluent $-\overrightarrow{-}$ injected control rats. The average weight of the ${ }_{\sigma}^{\bar{\omega}}$ adrenal glands of the cortisone-treated males wase $23 \mathrm{mg}$., also distinctly less than those of the average? inanition control male rat (40 mg.), and of the $\vec{N}$ average male diluent-treated control rat $(33 \mathrm{mg}$.). i

On the 7th day of the recovery period, the average $\stackrel{N}{-}$ weight of the adrenal glands of the female rats in each series (diluent-injected controls, inanition? controls, and cortisone-treated) ranged between $\vec{\infty}$ 45 and $52 \mathrm{mg}$.; 30 days after treatment they ranged between 52 and $55 \mathrm{mg}$. The weight of the adrenals of all the males in each series at 7 days after treat $\frac{3}{6}$ ment ranged between 34 and $38 \mathrm{mg}$.; at 30 days they® ranged between 29 and $39 \mathrm{mg}$. The weight of the $\vec{c}$ adrenals of the untreated control rats averageds $29 \mathrm{mg}$.

Ratio of Body Weight to Adrenal Weight.-Since@ the cortisone-treated male rats during the recovery period had a greater and more rapid gain in body⿳亠口冋. weight than the female rats of that series (Fig. 1), it $\$$ was thought that a more accurate evaluation of the $\vec{F}$ cortisone effect upon the adrenals could be obtained $\frac{3}{3}$ if the ratio of body weight to adrenal weight was considered rather than simply the weight of the adrenal glands (Fig. 2, opposite). For ease in representation, the body weight-àdrenal weight ratio was divided by 1,000 . The smaller the adrenal weight, the higher the ratio, and conversely, an increase inô weight of the adrenal during recovery is indicated by ao lower ratio. It is evident $\rightarrow$ that the ratio of body weight? to adrenal weight in the rats which received cortisone re-o flects a greater cortisone 0 effect upon the glands of the N male rats. Of interest is theo observation that the curve of ratios of the cortisonetreated male rats dropped? below the base line set by the 0 


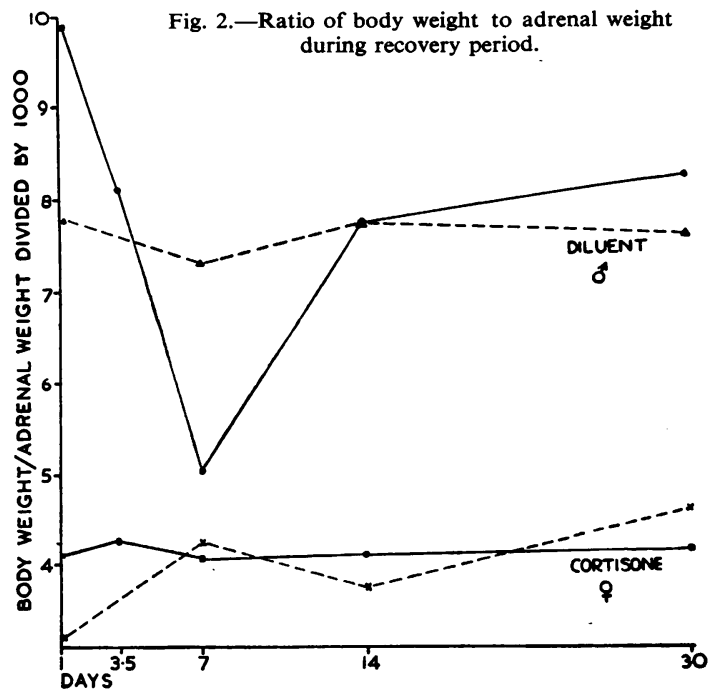

male diluent-injected control rats. A reasonable interpretation of this is that the more rapid increase in the adrenal weight of the cortisone-treated male rat is not in proportion to the gain in its body weight. The ratio in the rats which were injected with diluent showed only slight fluctuation during the recovery period. Neither the cortisone-treated female rats nor the diluent-treated rats of either sex showed a change in ratio as marked as did the cortisonetreated male rats.

Histological Findings.-At the end of the injection period, the cortisone-treated male rats showed a loss of lipid and a narrowing of the adrenal cortex as compared with the male control rats (cf. Fig. 3 with Figs 4 and 5, overleaf). Both these changes were present on the 7th day of the recovery period, but, by the 14th day, the adrenals of the male rats revealed slightly more lipid than was observed in the inanition control animals (Fig. 4), and the diluent control animals (Fig. 5).

At the end of the injection period, the adrenal glands of the cortisone-treated female rats showed slightly narrowed cortices and less sudanophilic substance than those of their inanition controls. These glands were also larger and paler; 3.5 days later the cortices were narrowed but showed somewhat more sudanophilic substance than those of the inanition control rats; 7 days later the adrenal glands of the female rats were normal.

The decrease of sudanophilic substance in the adrenals of cortisone-treated rats appeared first in the inner half of the cortex and later in the remainder. In those rats which showed the greatest cortisone effect the adrenal glands usually had a sudanophobic

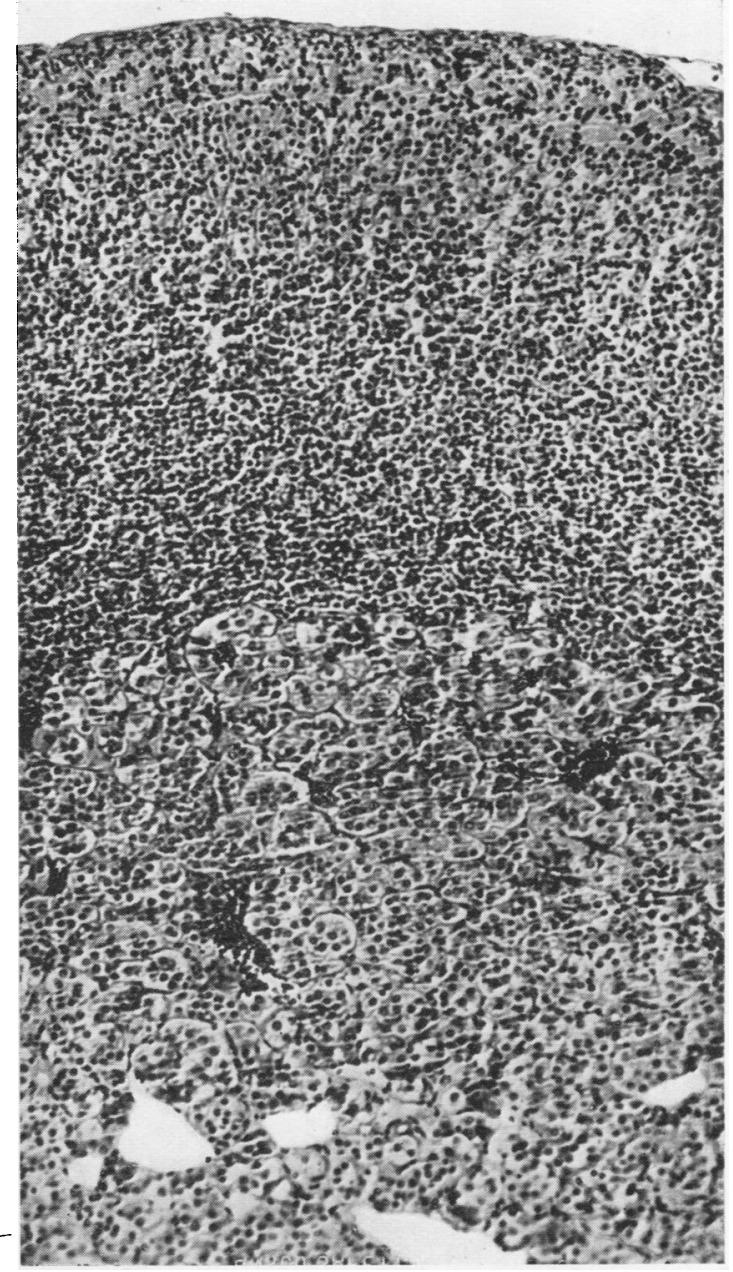

Fig. 3.-Section of adrenal gland from male rat killed after 11 days of cortisone acetate. Haematoxylin and eosin. $\times 135$.

zone several cells wide in the juxta-glomerular region of the fascicular zone.

The adrenal glands of the cortisone-treated female rats tended to be larger than those of the treated male rats, and had larger, paler fasciculata cells with looser cytoplasm; they revealed a sharper demarcation between the glomerulosa and fasciculata zones and had more sudanophilic substance. The adrenal glands from treated males always revealed less lipid than the glands from similarly treated female rats.

\section{Discussion}

It is difficult to relate many studies of the effects of cortisone in small laboratory animals to clinical experiences, because of the comparatively large 


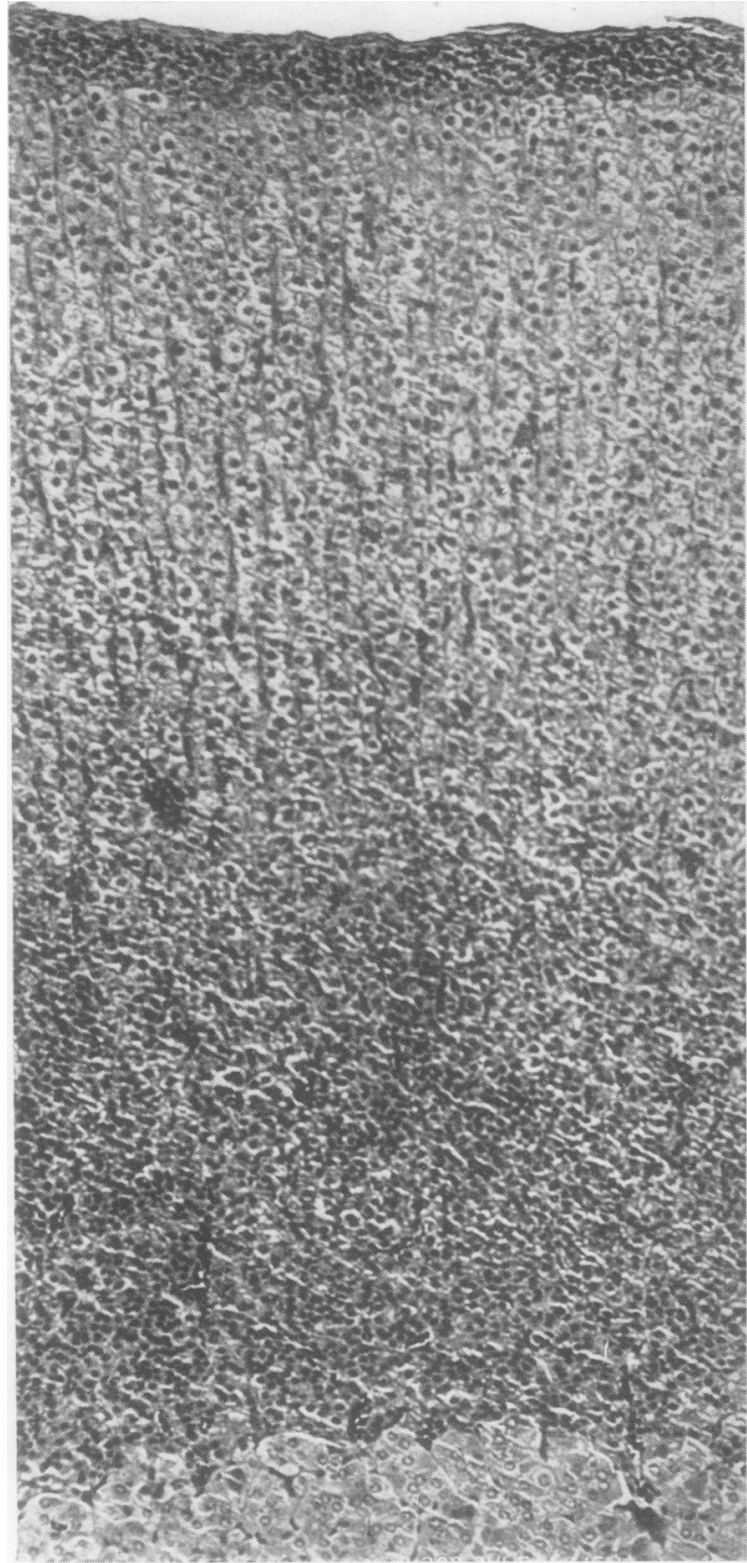

Fig. 4.-Section of adrenal gland from male inanition control rat of equal weight. Haematoxylin and eosin. $\times 135$.

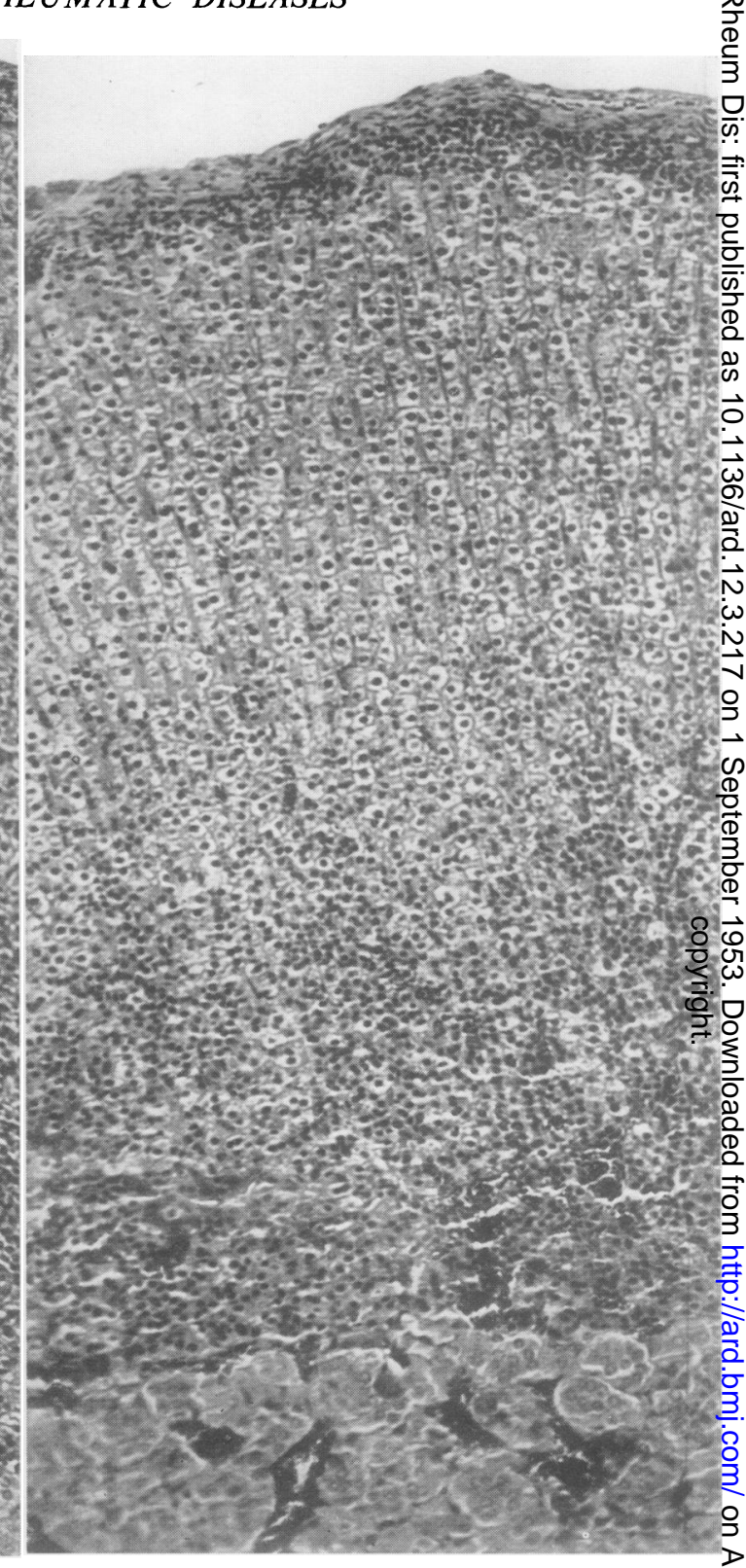

Fig. 5.-Section of adrenal gland from male control rat injected with diluent. Haematoxylin and eosin. $\because 135$

doses of steroid often used in the animal investigations. Our studies have been conceived to employ doses in animals more comparable to doses used in patients. In attempting to make the animal studies more accurately parallel clinical observations, the amount of steroid injected into the rat is important. 
sequent daily dose. Trials showed that the dose of $0.33 \mathrm{mg}$. daily for 10 days following an initial dose of $1 \mathrm{mg}$. produced adrenal gland changes which were too small to permit clear evaluation of reversibility or recovery. A daily dose of $5 \mathrm{mg}$. cortisone acetate intramuscularly was tried empirically in a few rats. These animals not only lost weight while receiving cortisone, but continued to lose during the posttreatment period, and it appeared that they would not survive the experiment. In some of these rats which were killed 3.5 days after cortisone was stopped the adrenal glands were extremely small, weighing less than $10 \mathrm{mg}$. each. Because it was obvious that $5 \mathrm{mg}$. cortisone acetate daily could not be tolerated, the dose was reduced to $3 \mathrm{mg}$. daily (still for the rat, equivalent to ten times an average daily dose of $100 \mathrm{mg}$. for a human being). This amount of cortisone acetate caused a decrease in the weight of the adrenal glands and histological alterations in these glands which include loss of lipid in the cortical cells.

The cortisone treatment period for the rat was made to correspond to a year of human life, determined in the following way: One year is 1.5 per cent. of the current human life expectancy (67 years). This percentage of the life expectancy of the rat ( 2 years) is 11 days. Therefore, the rats were injected with cortisone acetate for 11 consecutive days. Different groups of rats were killed 1, 3, 5, 7, 14, and 30 days after cessation of treatment, intervals corresponding to approximately $1,4,8,15$, and 33 months of human life.

Other investigators have reported loss of adrenal weight in cortisone-treated rats. Winter, Silber, and Stoerk (1950) reported that in male white rats which had received daily subcutaneous injections of $3 \mathrm{mg}$. cortisone acetate for 10 days, "the adrenal glands lost about 40 per cent. of their weight". It is inferred that this was in reference to adrenal gland weight of their control rats. Lewis, Rosemberg, and Wilkins (1950) injected female albino rats with $1 \cdot 25 \mathrm{mg}$. cortisone acetate daily for 20 days and found that the adrenal glands were 32 per cent. smaller than in normal controls. In our study, the adrenal glands of cortisone-treated rats of both sexes at the end of the injection period weighed 29 per cent. less than those of control animals. However, when the adrenal weight loss was related to body weight loss at the end of the injection period there was a sex difference. Although the number of animals in our untreated growth control series (I) was small, the work of Hatai (1913) in which he related adrenal gland weight to body weight in normal male and female albino rats, supports our present findings. He showed that after the body weight reached $30 \mathrm{~g}$., the adrenal glands of female rats consistently weighed more than the adrenal glands of male rats of the same body weight. Thus there is a normal sex difference in the adrenal weight of the albino rat, but this difference may be accentuated by cortisone-induced atrophy.

There was also a sex difference in the histological changes induced by cortisone in the rat adrenal glands. The male rats showed a greater loss of lipid. Winter, Silber, and Stoerk, working with male rats, reported 'virtually complete loss of lipid". In addition, a sex difference was noted in the rats at which the adrenal atrophy became reversed. Histologically the female rat adrenal was normal at 7 days after the last injection of cortisone, while the male rat adrenal had not returned to normal until the 14th day of the recovery period. Stebbins (1950), using male rats only treated by daily subcutaneous injection of $3 \mathrm{mg}$. cortisone acetate for 10 days and for 40 days, noted adrenal gland recovery within 17 days after cortisone was stopped.

We are cognizant of the fallacy of assuming that because the rat adrenal recovers completely from the effect of cortisone administration that human adrenal changes associated with cortisone therapy would certainly be reversible. However, Sokoloff, Sharp, and Kaufman (1951) reported no histological abnormality in the adrenals of a patient with rheumatoid arthritis who had received $16 \cdot 7 \mathrm{~g}$. cortisone, and died 19 days after steroid therapy was discontinued. O'Donnell, Fajans, and Weinbaum (1951) reported evidence of the reversibility of adrenal atrophy in a man with generalized scleroderma who received $1,050 \mathrm{mg}$. cortisone during a 12-day period, but who had received none for 17 days prior to necropsy.

Although the number of animals used in this experiment and the human findings to date are too few to draw an indisputable conclusion, it does seem apparent from the material here presented that the administration of high doses of cortisone has a similar effect upon the adrenal glands of rats and of man. It seems equally apparent that a few weeks after the withdrawal of the steroid the adrenal in both the rat and man no longer shows atrophy, thus indicating that the effect of cortisone is reversible.

\section{Summary}

The administration of cortisone acetate daily for 11 days to mature albino rats resulted in a decrease in body weight. The weight of male rats returned to the pre-injection level 7 days after treatment was stopped; the female rats required 30 days to regain their weight after discontinuation of cortisone. Untreated (control) animals showed essentially normal weight. 
At the end of the injection period, the adrenal glands of the cortisone-treated rats of each sex weighed 29 per cent. less than those of the diluent control animals. The ratio of body weight to adrenal weight at the end of the injection period was greater in the male than in the female rats, and it continued so throughout the recovery period up to 30 days, when the experiment was concluded. During recovery, the weight of the adrenal glands in the male animals increased more rapidly than body weight, giving a low ratio at 7 days.

The effect of cortisone upon the histological changes in the adrenal glands was greater in degree and of longer duration in the male than in the female rats. Narrowing of the adrenal cortex and decrease in lipid content in the cells were still present in the male rats on the 7 th day of recovery, at which time the appearance of the adrenals of the female had returned to normal.

These changes in body weight and in the histology of the rat adrenal glands were completely reversible. Recovery occurred more quickly in the female than in the male rats.

Technical assistance was rendered in these experiments by Miss P. Ford, Miss O. Federico, and Miss J. Kline.

\section{REFERENCES}

Hatai, S. (1913). Amer. J. Anat., 15, 87

Lewis, R. A., Rosemberg, E., and Wilkins, L. (1950). Endocrinology, 47, 414.

O'Donnell, W. M., Fajans, S. S., and Weinbaum, J. G. (1951). Arch intern. Med, $8 \mathbf{8}, 28$.

Sokoloff, L., Sharp, J. T., and Kaufman, E. H. (1951). Ibid., 88, 627. Stebbins, R. B. (1950). Fed. Proc., 9, 345.

Winter, C. A., Silber, R. H., and Stoerk, H. C. (1950). Endocrinology, 47,60 .

Rétablissement des altérations structurelles provoquées dans les glandes surrénales du rat par l'administration de la cortisone

RÉSUMÉ

L'administration de l'acétate de cortisone pendant 11 jours consécutifs aux rats albinos adultes provoqua una baisse pondérale du corps. Après l'interruption du traitement les rats mâles récupérèrent leur poids au bout de 7 jours et les femelles au bout de 30 jours. Le poids des animaux témoins demeura essentiellement normal.

A la fin de la série d'injections le poids des surrénales des rats des deux sexes traités par la cortisone fut inférieur $\frac{}{\overline{3}}$ de 29 pour cent à celui des rats témoins. Le rapport entre le poids du corps et le poids des surrénales à la fin de laㅡㅡ. série d'injections fut plus grand chez les mâles pendant ? toute la période récupérative de 30 jours, déterminée par $\vec{F}$ la durée de l'expérience. Pendant cette période chez $\stackrel{\mathcal{S}}{+}$ le mâle le poids des surrénales augmentait plus rapide-O ment que le poids du corps et ce rapport atteignit uno chiffre bas au bout de 7 jours.

L'effet de la cortisone sur les altérations histologiques des surrénales fut plus prononcé et plus durable chez les@ mâles que chez les femelles. Le rétrécissement de l'écorce@ surrénale et la diminution des lipides cellulaires furent ${ }^{\mathrm{s}}$ encore présents chez le mâle le 7 -me jour de la récupéra- $\vec{\circ}$ tion, alors que l'apparence des surrénales femelles fut $\rightarrow$ déjà normale.

Les altérations pondérales du corps et histologiquesळ de la glande surrénale des rats furent totalement reversibles. La récupération eut lieu plus rapidement chez? les femelles que chez les mâles. Restablecimiento de las alteraciones estructurales provo-iv cadas en las glándulas suprarrenales de la rata por administración de la cortisona

\section{SUMARIO}

La administración de acetato de cortisona durante oncecs días consecutivos a ratas albinas provocó una baja de peso del cuerpo. Al interrumpir el tratamiento, los machos recobraron el peso anterior al cabo de 7 días, 3 mientras las henbras necesitaron para esto 30 días. Elo peso de los animales de control quedó esencialmente normal.

Al terminar la serie de inyecciones, el peso de suprarrenales de las ratas de ambos sexos tratados cor cortisona fué inferior de 29 por ciento al de las ratas control. La razón: peso del cuerpo/peso de las supratr-o renales al cabo de la serie de inyecciones fué mayor en los machos que en las hembras, permaneciendo así durante el período de restablecimiento de 30 días, al cabo ٌ de los cuales se terminó la investigación. Durante el $\mathbb{Q}$ restablecimiento, el peso de las suprarrenales en los machos aumentaba más rápidamente que el peso del $\bar{\partial}$ cuerpo dando un cociente bajo a los siete días.

El efecto de la cortisona sobre las alteraciones histo- $\bar{Z}$ lógicas de las suprarrenales fué más pronunciado y más durable en los machos que en las hembras. La estrechez de la corteza suprarrenal y la disminución de los lípidos celulares existieron todavía en los machos el séptimo día de restablecimiento, mientras que la apariencia de las $\overline{0}$ suprarrenales de las hembras ya fué normal.

Las alteraciones ponderales del cuerpo e histológicas de la glándula suprarrenal de las ratas fueron completamente reversibles. El restablecimiento ocurrió más rápidamente en las hembras que en los machos. 